1. Albert, Tacon. Metian Global overview on the use of fish meal and fish oil in industrially compounded aquafeeds: Trends and future prospects. USA. J. Aquaculture. - 2008. - P. 146-158.

2. Артеменков Д.В., Власов В.А. Выращивание клариевого сома (Clarias gariepinus) в УЗВ на высокопротеиновых комбикормах с добавками пробиотика Субтилис. Международной научной конференции молодых ученых и специилистов, РГАУ-МСХА имени К.А. Тимирязева. - 2011. - C.34-37.

3. Davies, O.A.; Ezenwa, N.C. Groundnut cake as alternative protein source in the diet of Clarias gariepinus fry. Int. J. Sci. Nat. 2010, 1, 73-76.

4. Li, M.H. and E.H. Robinson Feed ingredients and feeds for channel catfish. 2013. No. 1806, 1-6.

5. Сгоров Б. В. Технологія виробниитва комбікормів. - Одеса: Друкарський дім, 2011. - 448 с.

6. Желтов, Ю.А. Кормление разновозрастных иенных видов рыб в фермерских рыбных хозяйствах [Текст] / Ю.А. Желтов. - Киев : ИНКОС, 2006. - $221 \mathrm{c}$.

7. Скляров, В.Я. Справочник по кормлению рыб [Текст] / В.Я. Скляров, Е.А. Гамызин, Л.П. Рыюков. - М.: Легкая и пищевая промышленность, 1984. - 120с.

8. Dedeke, G.A., S.O. Owa, K.B. Olurin, A.O. Akinfe, and O.O. Awotedu, Partial replacement of fish meal by earthworm meal (Libyodrilus violaceus) in diets for African catfish, Clarias gariepinus International Journal of Fisheries and Aquaculture, 2013. 5(9): p. 229-233.

9. Єгоров Б.В. Особливості виробництва комбікормів для риб/ Сгоров Б.В., Фігурська Л.В. / Хранение и переработка зерна, №12, - C. 58-60.

10. Eл. pecypc http://vismar-aqua.com/vpershe-konferentsiya-na-temu-klariyevij-som-perspektivi-viroshhuvannya-v-ukrayini.html.

11. Електронний ресурс https://interfax.com.ua/news/economic/415515.html

12. Latest Facts for Fish and Shrimp Feed Formulations (NRC bulletin on Nutrient Requirements for Fish and Shrimp, John E. Halver, Ph.D., NAS, MTA School of Aquatic \& Fishery Sciences University of Washington, Seattle, WA. USA.

13. Сгоров, Б.В. Особливості формування рецептів комбікормів для форелі [Текст] / Б.В. Сгоров, Л.В. Фігурська // Зернові продукти і комбікорми. - 2012. - № 1. - С. 13-18.

14. Сгоров, Б.В. Аналіз технологічних способів виробництва комбікормів для риб [Текст] / Б.В. Сгоров, Л.В. Фігурська // Зернові продукти і комбікорми. - 2012. - № 1. - С. 35-42.

15. Steffens, W. Principles of fish nutrition [Text] / W. Steffens. - England: Chichester, 1989. - 384 p.

16. Fagbenro, O.A., Balogun A.M., Fasakin E.A., Bello-Olusoji O.A.. 1998b. Dietary lysine requirement of the African catfish, Clarias gariepinus. Journal of Applied Aquaculture 8(2): 71-77.

17. Verreth J. van Tongeren M. Weaning Time in Clarias gariepinus (Burchell, 1822) Larvae.//Aquaculture/ - 1989. - V.83/ P.81-88.

18. .Артеменков Д.В., Власов В.А. Выращивание клариевого сома (Clarias gariepinus) в УЗВ на высокопротеиновых комбикормах с добавками пробиотика Субтилис. Международной научной конференции молодых ученых и специалистов, РГАУ-МСХА имени К.А. Тимирязева. - 2011. - С.34-37.

19. Davies, O.A.; Ezenwa, N.C. Groundnut cake as alternative protein source in the diet of Clarias gariepinus fry. Int. J.Sci.Nat. 2010, 1,73.

20. Li, M.H., Robinson E.H. Feed ingredients and feeds for channel catfish. 2013. No. 1806, 1-6.

Надійшла 14.02.2019. До друку 25.02.2019.

Рецензія 20.02.2019

Адреса для переписки:

65039, Odessa, str. Kanatnaya 104, r. A 224

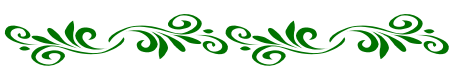

UDK 636.661.73(075.8)

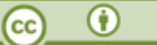

A.V. MAKARYNSKA, PhD. Sc., Associate Professor,

N.V. VORONA, PhD. Sc., Associate Professor, Department of Feed and Biofuel Technologies

Odessa National Academy of Food Technologies, Odessa, Ukraine

\title{
USING OF BIOTESTING IN SAFTY ASSESMENT OF THE EXTRUDED FEED ADDITIVE WITH ALGAE
}

\footnotetext{
Abstract

The article is devoted to the problems of determining quality and safety of extruded feed additive (EFA) with algae. It is used in the production of mixed feed and premixes.

It is proved that the safety of finished food products depends on the safety of feed and feed raw materials. The list of conditions for obtaining safe finished products is given. Today traditional methods of analytical chemistry, express and toxicological methods (marking, biotesting) are used for the analysis of feed safety.

The expediency of use of brown algae in the composition of feed products is substantiated. The brightest representative of brown algae is Laminaria. The technology of using Laminaria algae in the composition of feed products in the form of extruded feed additive is proposed.

The method of determination of organicity by methods of biotesting is given: biocrystallization method, determination of the oxidation-reduction potential index (ORP), organicity using Colpoda steinii culture. Indicators of organicity are given.

An analysis of experimental samples biocrystalograms suggests that EFA is environmentally safe and do not endanger the environment or the health and life of animals and humans. When determining the ORP of the EFA with algae it was established that the product is easily digestible, since it has a biological compatibility with the animal organism.
} 
The expediency of using the process of extrusion to reduce the toxicity of algae is established. The application of the extrusion allows to add up to $15 \%$ Laminaria algae to the feed.

The results of biological studies of EFA in vivo are presented, which indicate a high biological efficiency of the use of algal feed supplement in the composition of feed for young farm birds in the amount of up to $25 \%$, since the average daily weight gain of rats increases and the cost of feed decreases. potential (ORP).

Ключові слова: extruded feed additive (EFA) with algae, biotesting, organicity, biocrystalogram, the oxidation-reduction

\section{Introduction}

The safety of the final products of animal origin depends on the safety of feed and feed raw materials used for its production. In Ukraine the Law No. 2845 «About safety and hygiene of feed» was adopted in december 2017. It allows creating conditions for the development of the feed market in Ukraine and promotes the growth of the quality and safe feed production. Safe feed are the feed that does not have a negative impact on the health of people or animals or the feed that does not make food products of animal origin dangerous for human consumption.

The safety of feed depends on: the quality of feed raw materials; the conditions of its transportation and storage; technological process of production. The safety and quality of feed raw materials and feed products are determined using analytical methods accredited by the National Accreditation Agency of Ukraine or the relevant foreign accreditation system.

Along with traditional methods of analytical chemistry today express and toxicological methods of analysis, for example, marking, biotesting, become widespread. Modern biotesting methods are based on determining the action of toxicants on specially selected organisms in standard conditions with the registration of various behavioral, physiological or biochemical parameters $[1$, p. 17-20].

In the world feed industry today the use of seaweed is of great importance in the form of flour, crumb and suspensions. In the feed industry brown algae are the most widespread due to the greatest yield, ease harvesting and other properties. The use of seaweed in the composition of feed allows to balance feed by microelements and to reduce the need for antibiotics. Brown algae contain a significant amount of amino acids, including methionine, valine, isoleucine compared to other types of algae. The brightest representative of brown algae is Laminaria [2, p. 1-17; 3, p. 74-84; 4, p. 389-420].

The technology of obtaining an extruded feed additive (EFA) using the Laminaria algae has been de-

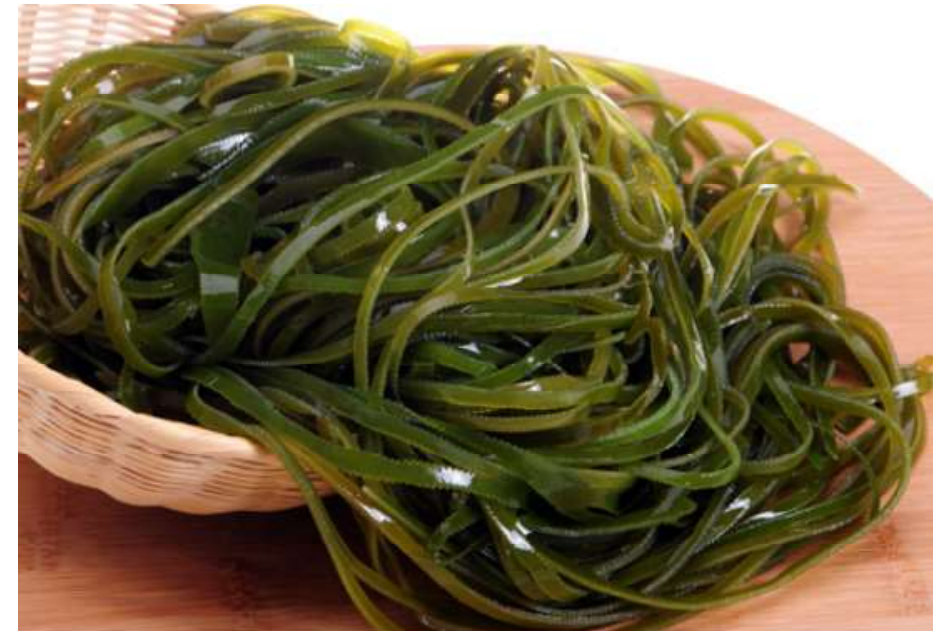

veloped in the Odesa National Academy of Food Technologies at the Department of Feed Technology and Biofuel. The mass fraction of algae is $12,5 \ldots 15,0 \%$ in the additive. This technology includes the dosage and mixing of pre-ground algae and grain, the extrusion of the resulting mixture, the cooling and the grinding of the finished extrudate. This method can significantly reduce the cost of preparing algae by eliminating the energy-intensive drying process, and expand the assortment of feed products. The obtained additive can be used separately or as a component of mixed feed, PVA, PVMA, premixes [5, $\mathrm{p}$. 28-29; 6, p. 44-50].

The obtained extruded feed additive with the algae is characterized by a significant content of mineral substances $(2,15 \%)$, raw protein $(9,13 \%)$, polysaccharides, vitamins. Ash contains a significant amount of iodine (45.96 mg / kg). In contrast to inorganic iodine, it has high bioavailability because it is in combination with proteins. However, the percentage of algae and additives with significant content of iodine in the composition of mixed feed should not exceed $5 \%$ to avoid risk of poisoning and illness of animals and poultry [7, p. 278-290]. In addition, algae grown in natural conditions, especially in areas with a difficult ecological condition, can accumulate toxic substances from reservoirs. This is due to the significant sorption capacity of algae and considerably restricts their use in the composition of mixed feed.

Today, the issue of determining the organicity of feed raw materials, feed additives and mixed feed by experimental methods is acquiring significant relevance. In scientific works $[1$, p. $17-20 ; 8$, p. 18-23] the expediency of determining the criterion of feed and food products organicity according to the values of organoleptic quality indices, complex safety indicators, comprehensive indicators of nativeness and indicators of products biological activity was substantiated.

The purpose of the study was to assess the organic and ecological nature of the extruded feed additive with algae using biotesting methods.

\footnotetext{
Materials and methods of research

Research objects: Laminaria algae, crushed grain of corn, feed additive with algae before and after extrusion at the following ratio of algae to grain of corn: sample number 1 - 10:90; sample number 2 - 12.5: 87.5; sample number 3 15:85.

Indicators of organicity were determined using a set of biotesting methods:

- a certified method of biocrystallization (crystallographic method), which is based on a qualitative and quantitative description and interpretation of crystalline formation of biosubstrate products and water in the presence of $\mathrm{CuCl}_{2}$ salt $[9$, p. $97-104 ; 10$, p. 1-23];
} 
- index of oxidation-reduction potential (ORP) of hydrogen solutions of experimental samples using ORP-200 ORP-meter. In order to determine the ORP in appropriate ratios the samples were mixed with distilled water for 30 minutes at room temperature and were left for 15 minutes to precipitate the particles and form a precipitate. After filtration of the obtained aqueous extract its value of ORP was determined by immersing the ORPmeter electrodes into a test fluid reservoir. The values of ORP were fixed after stabilizing the electronic indexes on the screen for 10-15 minutes. [11, p. 32-47];

- organicity using Colpoda steinii culture. The research was conducted in accordance with GOST R 52337-2005. The live dry cysts of Colpoda steinii infusion in a nutrient medium have the ability to excystation after a 16-hour incubation at a temperature of $28{ }^{\circ} \mathrm{C}$. They lose mobility in contact with toxic substances. The degree of toxicity of the experimental sample is determining by the time after which the infusions stop moving indicates [12, p. 37-48]. The suspension with excystic infusions was combined with an equal volume of the experimental sample at an incubation temperature of $28^{\circ} \mathrm{C}$. A drop of the mixture was seen in a crushed drop under a microscope with an increase of $80 \times 150$. The condition monitoring of infusion Colpoda Steinii in control and experimental samples was carried out during the first 3 minutes; 10 minutes and 3 hours.

\section{Research results}

The evaluation of the organicity indicators of the experimental samples was carried out visually on the following indicators: morphological features - features of curly needles, local features, interconnection of individual morphological features, symmetry of the picture, textural features (structure density, regularity of branches), overall image quality (integration, coordination).
Biocrystalograms of experimental samples are presented on Fig. 1 and 2.

The symmetry of the drawings, the size of the crystals and their branching for the obtained biocrystalograms of the experimental samples (Fig. 1) indicate their natural origin. This is due to the fact that the shapes of the formed crystals needles are not deformed, straight and have different lengths, and the branches are all similar to each other.

The structure is not very dense, the needles are straight - not curved. Such a character of biocrystalograms suggests that during the cultivation and subsequent processing of algae and grain raw materials, substances that could affect the structure of finished products were not used. Consequently, these algae and grain raw materials are environmentally safe and do not endanger the environment or the health and life of animals and humans.

For biocrystalograms of the EFA with algae (Fig. 2) a more needle-shaped branched form of crystals on the limbs is characteristic. This is due to the chemical changes in the components, namely dextrinization of starch and the formation of a stable carbohydrate-protein complex during the extrusion of experimental mixtures.

One of the important factors in the regulation of the parameters of oxidative-reducing reactions occurring in any liquid medium is the activity of electrons or ORP of this medium. Normal ORP of the internal environment of the animal's organism is in the range from -200 to $+100 \mathrm{mV}$. This means that the internal environment of the organism is in a restored condition.

When determining the ORP of the EFA with algae it was established that the value of the ORP is within the range of $+129,0 \ldots+144,0 \mathrm{mV}$ (Fig.3).

This corresponds to the value of the ORP of the internal environment of the animal's organism. Thus, the

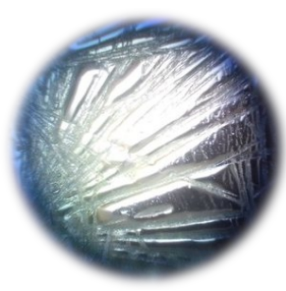

1

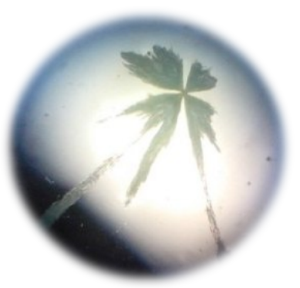

2

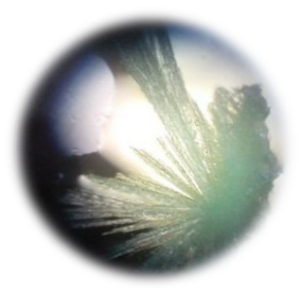

3

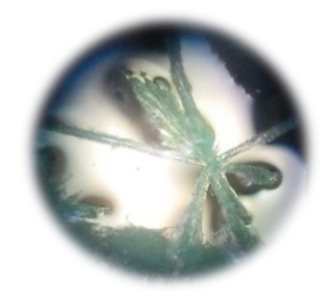

4

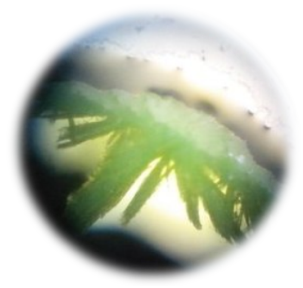

5

Fig. 1 - Biocrystalograms of the experimental samples before extrusion: 1 -water control; 2 - initial corn;

3 -Sample number 1-10:90; 4-Sample number 2-12,5:87,5; 5-Sample number 3-15:85

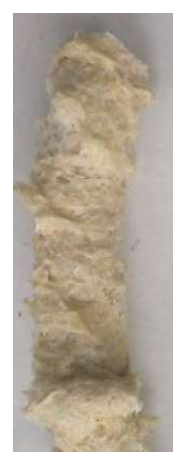

2

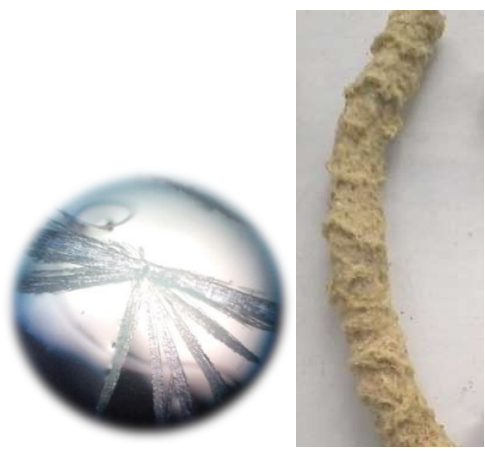

3

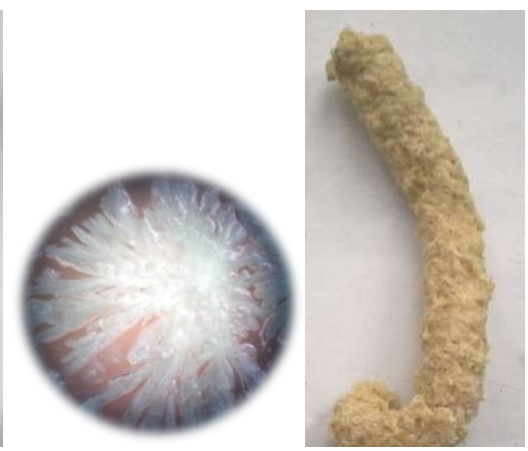

4

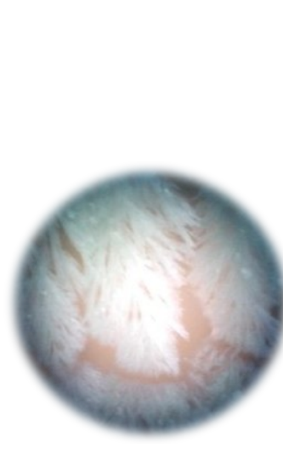

5

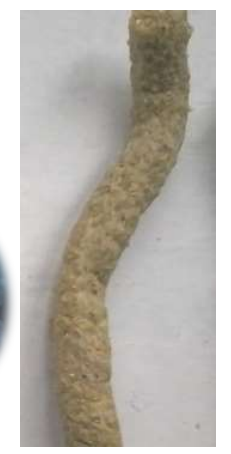

Fig. 2 - Biocrystalograms of the experimental samples after extrusion:

3 -Sample number 1-10:90; 4-Sample number 2 -12,5:87,5; 5 -Sample number 3 - 15:85 
electrical energy of cell membranes will not be spent on correction of the activity of electrons, and the product will be easily digested, since it has a biological compatibility with the animal's organism.

The degree of toxicity of EFA with algae was evaluated according to the scale of toxicity assessment:

- very toxic (the death of most Colpoda steinii comes within 3 minutes);

- toxic (the death of most Colpoda steinii comes within 10 minutes);

- slightly toxic (the death of most Colpoda steinii comes after 3 hours);

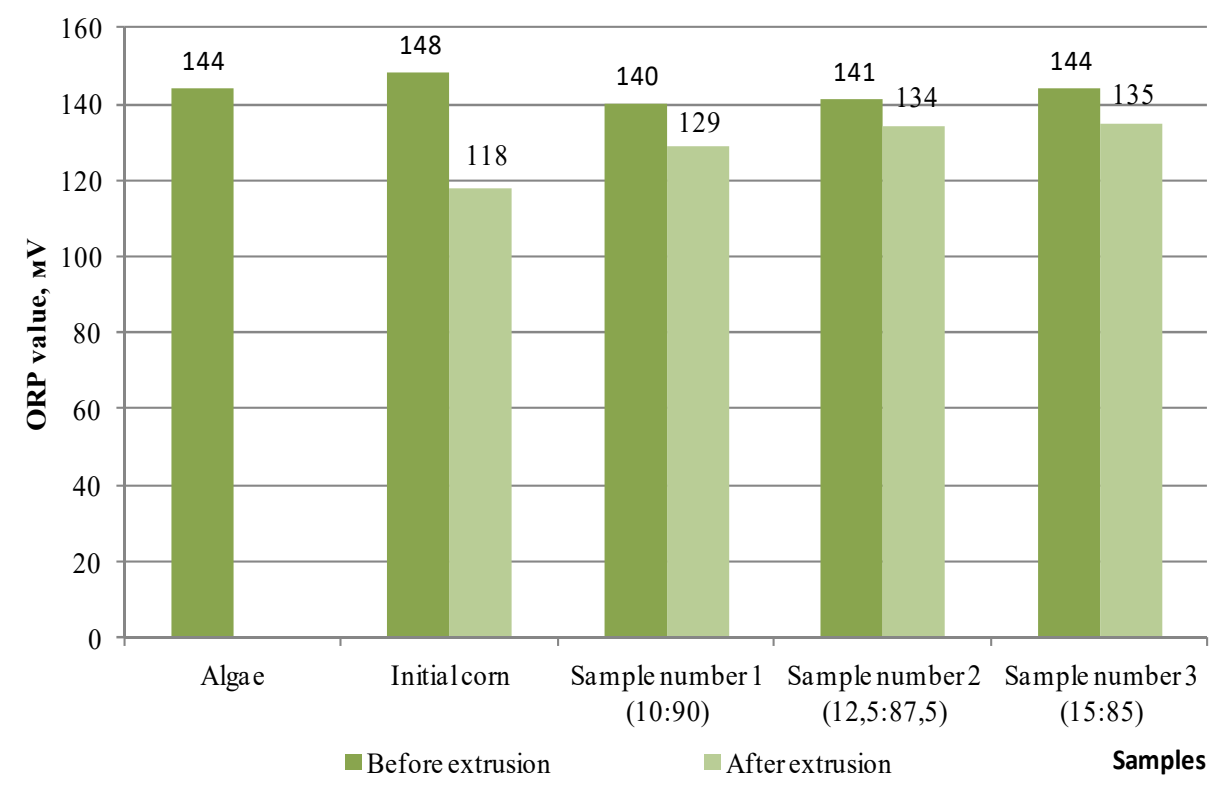

Fig. 3 - The value of ORP for feed additive with algae before and after extrusion

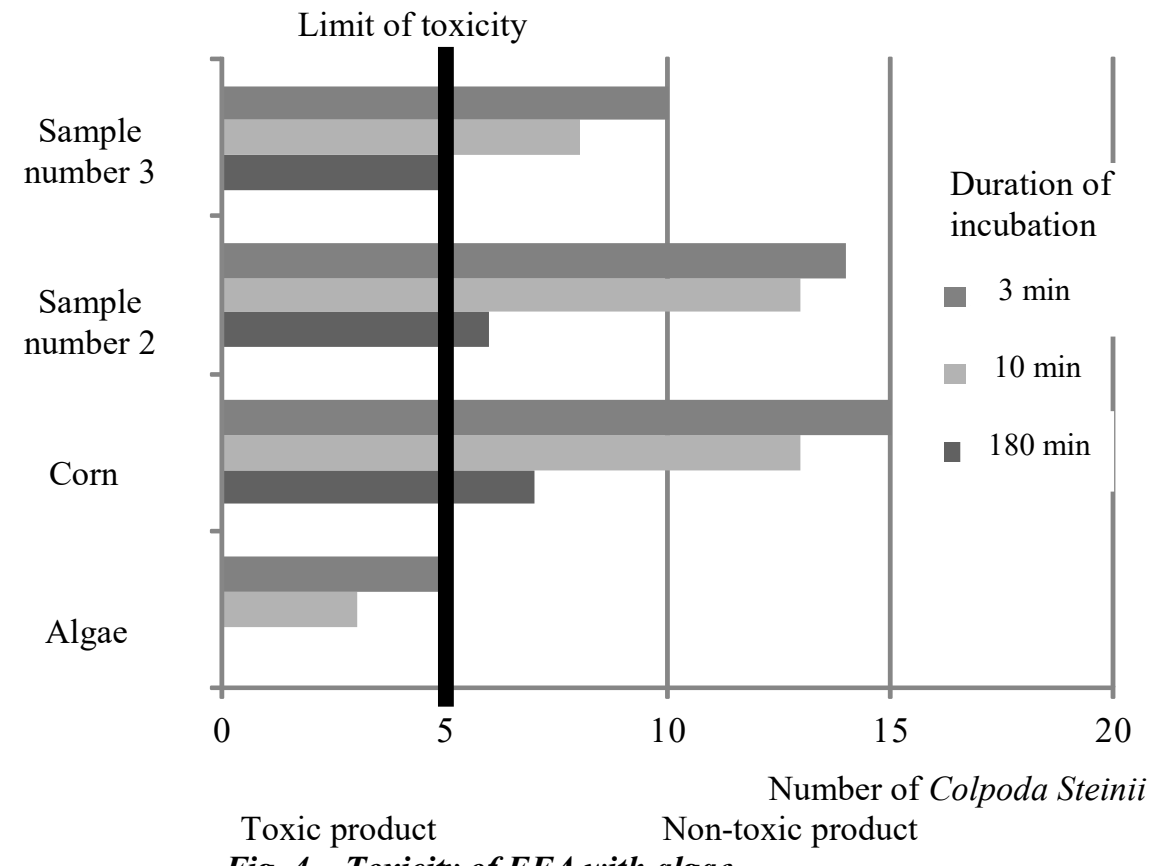

Fig. 4 - Toxicity of $\mathrm{EFA}$ with algae

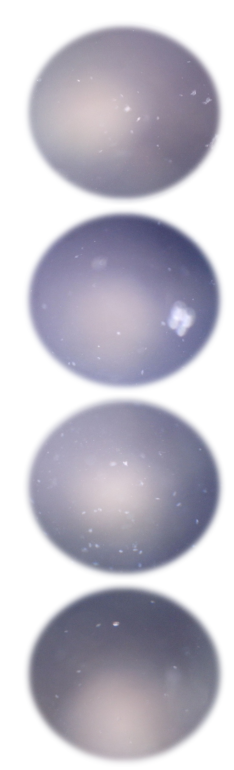

Culture Colpoda steinii (an increase of 80x150)
- - not toxic (for 3 hours most of Colpoda steinii remain mobile).

The results of the determination of complex ecological and toxicological indicators of safety of the finished EFA with algae by the method of biotesting using Colpoda steinii are presented in Fig. 4. As can be seen from the data in Fig. 4 initial algae are a very toxic product, but they can not be used in feed without pretreatment.

The application of the extrusion allows to add up to $15 \%$ Laminaria algae to the feed, with the requirements not exceeding the limit of toxicity of the feed additive.

On the basis of the laboratory of biochemistry of the Institute of Stomatology of the Academy of Medical Sciences (Odessa) under in vivo conditions, a biological assessment of extruded algal supplement was carried out. Three groups of white rats at the age of 2 months were formed with an average live weight of 105.6; 1 control group consumed full-feed combi-feed for laying hens with extruded corn; 2 research group - complete feed with the inclusion of $25 \%$ EFA; 3 research group - full ration compound feed $3 \%$ of EFA (taking into account the daily iodine content in the recipe).

After 12 days, the average daily weight gains of rats in the control group 1 were $3.2 \pm 0.18 \mathrm{~g} /$ day, in the research 2 and 3 groups $-4.5 \pm 0.45$ and $4.0 \pm 0.36 \mathrm{~g} /$ day, which is $40.63 \%$ and $25.0 \%$ more than in the control, respectively. The absolute gains in live weight of rats in the control group were $38.8 \pm 2.13 \mathrm{~g} /$ goal, and in the experimental group $53.4 \pm 5.37$ and $48.4 \pm 4.34 \mathrm{~g} /$ goal. The relative weight gains of rats in the control group were $36.6 \pm 3.31 \%$ / goal, and in the experimental 2 and 3 groups, $47.2 \pm 5.88$ and $44.3 \pm 3.36 \% /$ goal respectively. The value of the absolute and relative increase in live weight of rats in the control and 
experimental group is within the experimental error.

The consumption of mixed feeds for all groups decreased from $20.4 \mathrm{~g} / 100 \mathrm{~g}$ of body weight at the beginning of the experiment to $17.3 \mathrm{~g} / 100 \mathrm{~g}$ of body weight by the end of the experiment, while the total consumption of mixed feeds in the groups increased with an increase in the body weight of rats on average from 20 at the beginning of the experiment to $24 \mathrm{~g}$ per day. The relative decrease in the feed that was consumed is associated with a decrease in the interest of the rats in new feed, the composition of which did not change during the experiment. The rest of the feed at the end of the day in the feeders was similar and ranged from $5 \pm 2 \mathrm{~g}$

In the experimental groups that consumed the compound feed with EFA there were no visible changes in the state of the hairline and mucous membranes of the oral cavity.
The lowest cost of feed was observed for the research group 2, consumed feed with a content of EFA $25 \%$. Feed conversion (feed costs for obtaining a gram of increase in body weight of rats) in the control group was $5.31 \mathrm{~g} / \mathrm{g}$, in research 2 and 3 groups -3.78 and $4.2 \mathrm{~g} / \mathrm{g}$, which is 28.81 and $19,96 \%$ less than in the control, respectively.

\section{Conclusions}

The conclusions from the results of experimental researches can be made about the possibility and perspectivity of the use of methods for the determination of organicity and biotesting in contrast with the traditional methods of safety assessments of feed products and its environmental labeling. For the production of safe EFA the content of algae in its composition should not exceed $15 \%$, and the additive itself in the feed - up to $25 \%$.

\section{REFERENCES}

1. Krusir H.V., Kiriyak A.V., Chernishova O.O. Ekolohichne markuvannya orhanichnikh kombikormiv // Zernovi produkti i kombikormi. 2015. T. 15, vip. 1. S. 17-20.

2. Show more Seaweeds for livestock diets: A review / Makkar H. et al. // Journal of Animal Feed Science and Technology. 2016. Vol. 212, No. 1. P. 1-17.

3. Seaweed as a protein source for mono-gastric livestock / Angell A. et al. // Trends in Food Science \& Technology. 2016. Vol. 54, No. 1. P. 74-84.

4. Rajauria G. Seaweeds: a sustainable feed source for livestock and aquaculture // Seaweed Sustainability. Food and Non-Food Applications: book/ ed. by Brijesh K. Tiwari and Declan J. Troy. Elsevier, 2015. Topic 15. P. 389-420.

5. Makarins 'ka A.V. Tekhnolohichni sposobi pererobki vodorostey / Zbirnik tez dopovidey 75 naukovoyi konferentsiyi vikladachiv akademiyi. Odesa: MON Ukrayini, ONAKhT, 2015. S. 28-29.

6. Makarinskaya A.V. Morskie vodorosli kak komponent kombikormov // Zernovi produkti i kombikormi. 2014. T. 14, vyp. 4. S. 44-50.

7. Fleurence J., Levine I. Seaweed in Health and Disease Prevention. 1st Edition: book. Academic Press: Academic Press, 2016. $476 \mathrm{p}$.

8. Mardar M.R., Krusir H.V., yanivs `ka A.I. Biotestuvannya v otsinyuvanni bezpechnosti zernovikh plastivtsiv // Zernovi produkti i kombikormi. 2014. T. 14, vip. 3. S. 18-23.

9. Kahl J., Busscher, N. \& Meier-Ploeger, A. Ganzheitliche Untersuchungs methoden zur Erfassung und Prüfung der Qualität ökologischer Lebensmittel: Stand der Entwicklung und Validierung: projekttitel. Bonn: Geschäftsstelle Bundesprogramm Ökologischer Landbau in der Bundesanstalt für Landwirtschaft und Ernährung, 2003. 265 p.

10. Standardization of the Biocrystallization Method for Carrot Samples / Busscher N. et al. // Biological Agriculture and Horticulture, Academic Publishers Printed in Great Britain. 2010. Vol. 27, No. 1. P. 1-23.

11. Shul ts M.A., Pisarevskiy A.M., Polozova I.P. Okislitel 'nyy potentsial. Teoriya i praktika : monohrafiya. L'vov: L, 1984. $168 \mathrm{~s}$.

12. Vinokhodov D.O. Nauchnye osnovy bitestirovaniya s ispol zovaniem infuzoriy : dis. na poluchenie nauch. stepeni dokt. biol. nauk: 03.00.23 : zashchita 16.03.2007/ nauch. ruk. R. Sankt-Peterburh: Sankt-Peterburhskiy tekhnolohicheskiy institut, 2007. 270 s.

А.В. МАКАРИНСЬКА, канд. техн. наук, доцент, Н.В. ВОРОНА, канд. техн. наук, доцент

\section{ВИКОРИСТАННЯ БІОТЕСТУВАННЯ В ОЦІНЮВАННІ БЕЗПЕЧНОСТІ

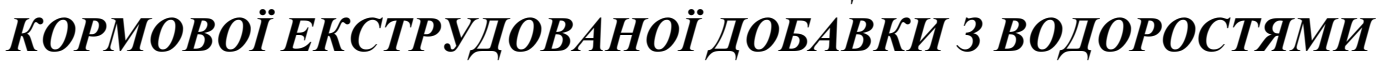

\footnotetext{
Анотація

Стаття присвячена проблемам визначення якості та безпечності екструдованої кормової добавки (ЕКД) з водоростями, яка застосовується при виробництві комбікормів і преміксів.

Доведено, щчо від безпеки комбікормової продукції $і$ кормової сировини залежить безпека готової харчової продукції. Наведено перелік умов отримання безпечної готової продукиії. Сьогодні для аналізу безпечності кормів використовують традиційні методи аналітичної хімії, експрес та токсикологічні методи (маркування, біотестування).

Обтрунтовано доцільність використання бурих водоростей у складі комбікормової продукиії. Найяскравішим представником бурих водоростей є Lатіпаria. Запропоновано технологію використання водорості Laminaria у складі комбікормової продукиї у вигляді екструдованої кормової добавки.

Викладено методику визначення органічності за допомогою методів біотестування: методу біокристалізації, визначення показника окисно-відновного потенщіалу (ОВП), органічності за допомогою культури Colpoda steinii. Наведено показники оцінки органічності.
} 
Аналіз біокристалограмм дослідних зразків свідчить, щяо ЕКД є екологічно безпечною та не має загрози для стану довкілля або здоров'я та життя тварин і людей. При визначенні ОВП ЕКД встановлено, що продукт легко засвоюється, оскільки володіє біологічною сумісністю з організмом тварин. Встановлено доцільність використання технологічного процесу екструдування для зниження токсичності водоростей. До складу ЕКД водорості можна вводити у кількості до $15 \%$.

Представлені результати біологічних досліджень ЕКД в умовах іп vivo, які свідчать про високу біологічну ефективність використання водоростевої кормової добавки у складі комбікормів для молодняка сільськогосподарської птиці в кількості до 25 \%, оскільки підвищуються середньодобові прирости маси тіла щурів та зменшуються витрати комбікормів.

Ключові слова: екструдована кормова добавка з водоростями, біотестування, органічність, біокристалограмма, окисно-відновлювальний потенціал.

\section{ЛІТЕРАТУРА}

1. Крусір Г.В., Кіріяк А.В., Чернишова О.О. Екологічне маркування органічних комбікормів // Зернові продукти і комбікорми. 2015. T. 15, вип. 1. С. 17-20.

2. Show more Seaweeds for livestock diets: A review / Makkar H. et al. // Journal of Animal Feed Science and Technology. 2016. Vol. 212, No. 1. P. 1-17.

3. Seaweed as a protein source for mono-gastric livestock / Angell A. et al. // Trends in Food Science \& Technology. 2016. Vol. 54, No. 1. P. 74-84.

4. Rajauria G. Seaweeds: a sustainable feed source for livestock and aquaculture // Seaweed Sustainability. Food and NonFood Applications: book/ed. by Brijesh K. Tiwari and Declan J. Troy. Elsevier, 2015. Topic 15. P. 389-420.

5. Макаринська А.В. Технологічні способи переробки водоростей / Збірник тез доповідей 75 наукової конферениії викладачів академії. Одеса: МОН Украӥни, ОНАХТ, 2015. С. 28-29.

6. Макаринская А.В. Морские водоросли как компонент комбикормов // Зернові продукти і комбікорми. 2014. T. 14, Bbin. 4. C. 44-50.

7. Fleurence J., Levine I. Seaweed in Health and Disease Prevention. 1st Edition: book. Academic Press, $2016.476 \mathrm{p}$

8. Мардар М.Р., Крусір Г.В., Янівська А.І. Біотестування в оцінюванні безпечності зернових пластівиів // Зернові продукти і комбікорми. 2014. T. 14, вип. 3. С. 18-23.

9. Kahl J., Busscher, N. \& Meier-Ploeger, A. Ganzheitliche Untersuchungs methoden zur Erfassung und Prüfung der Qualität ökologischer Lebensmittel: Stand der Entwicklung und Validierung: projekttitel. Bonn: Geschäftsstelle Bundesprogramm Ökologischer Landbau in der Bundesanstalt für Landwirtschaft und Ernährung, 2003. 265 p.

10. Standardization of the Biocrystallization Method for Carrot Samples / Busscher N. et al. // Biological Agriculture and Horticulture, Academic Publishers Printed in Great Britain. 2010. Vol. 27, No. 1. P. 1-23.

11. Шульи М.А., Писаревский А.М., Полозова И.П. Окислительный потенџиал. Теория и практика : монография. Львов: Л, 1984. 168c.

12. Виноходов Д.О. Научные основы биотестирования с использованием инфузорий : дис. на получение науч. степени докт. біол. наук: 03.00.23: защита 16.03.2007/ науч. рук. Р. Санкт-Петербург: Санкт-Петербургский технологический институт, 2007. 270 c.

Надійила 14.12.2018. До друку 05.01.2019.

Рецензія 25.12.2018

Адреса для переписки:

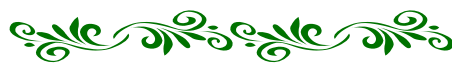

65039, Odessa, str. Kanatnaya 104, r. A 224.

UDK 634.4.084/27

(c) (i)

${ }^{1}$ O.Y. KARUNKYI, Dr. of Agricultural Sciences, Professor

${ }^{1}$ T.L. REZNIK, Postgraduate Student

${ }^{2}$ Ye.V. KULIDZHANOV,

${ }^{I}$ Odessa State Agrarian University, Odessa, Ukraine

${ }^{2}$ the Head of Affiliated State Centre "Ukrainian Institute of Soil Protection"

\section{CHLORELLA SUSPENSION AND ITS USAGE IN FINISHING PIGS' RATIONS}

Abstrakt

The animal husbandry cannot develop successfully without complete balanced feed and optimal forage supply.

This article deals with the chemical composition of chlorella suspension.

The ration is balanced with seaweeds as well as premixes, vitamins and bio supplement for the last decades. These seaweeds include chlorella - a representative of green microscopic algae.

The use of chlorella allows for multi-factor balancing of the diet in accordance with modern feeding standards, which increases the productive effect of feed and significantly increases the transformation of nutrients into livestock products. This is a relevant issue of modern animal husbandry.

The chlorella suspension was material for scientific research. It was made on the farm "In Samvel", Ovidiopol District.

According to the result of researches that took place on the farm "In Samvel", Biliayevka District, Odessa Oblast and SERF "Yuzhnyi" OSAGES NAAS, new data concerning chemical composition, the positive influence of investigated chlorella suspen- 